\title{
Floristic Diversity, Distribution and Analysis of Forest Cover Change in the Kedjom Keku Forest, NW Cameroon
}

\author{
Patrick Tsitoh, Eneke Esoeyang Tambe Bechem* \\ Department of Botany and Plant Physiology, University of Buea, Buea, Cameroon \\ Email: *tamenekeso@yahoo.co.uk
}

How to cite this paper: Tsitoh, P. and Bechem, E.E.T. (2019) Floristic Diversity, Distribution and Analysis of Forest Cover Change in the Kedjom Keku Forest, NW Cameroon. Open Journal of Ecology, 9, 273-292.

https://doi.org/10.4236/oje.2019.98020

Received: July 30, 2019

Accepted: August 25, 2019

Published: August 28, 2019

Copyright $\odot 2019$ by author(s) and Scientific Research Publishing Inc. This work is licensed under the Creative Commons Attribution International License (CC BY 4.0).

http://creativecommons.org/licenses/by/4.0/

\begin{abstract}
Conservation of tropical rainforest is an important aspect of climate change mitigation, and baseline information through inventories of forests is paramount so as to enable the putting in place of proper management strategies. This study was aimed at evaluating the plant species diversity, and distribution and to investigate the forest cover change of the Kedjom Keku forest. Five plots were located at irregular intervals $(100 \mathrm{~m} \times 50 \mathrm{~m})$ along a line transect and spread throughout the study area using $10 \mathrm{~m} \times 10 \mathrm{~m}$. Land cover/Land use changes were evaluated using remote sensing and GIS, while semi structured questionnaires were used to assess the anthropogenic activities. A total of 107 species of plants including 74 trees, 28 shrubs and 5 lianas, belonging to 83 genera and 58 families were identified. Rubiaceae (10 species) and Asteraceae ( 5 species) were the most represented tree and shrub families respectively. Species with the highest important value index were Schefflera mannii (31.9) and Piper capense (16.9) for trees and shrubs respectively. This forest is diverse, with Shannon-Wiener diversity index values of 3.55 for trees and 3.07 for shrubs. Seven land cover classes were distinguished within the years 1986, 2003 and 2018. There was a drastic increase in built up/settlement from $0.63 \%$ in 2003 , to $20.46 \%$ in 2018 . Dense vegetation increased within 2003 to 2018 after a drastic drop from $151.86 \mathrm{ha}^{-1}$ to $119.88 \mathrm{ha}^{-1}$ between 1986 and 2003. Infrastructure, over-grazing and expansion of farmland were reported as the direct factors influencing degradation, while land right, land tenure and equitability were the most cited indirect factors. The prominent factor that encouraged degradation was the fertile nature of the soils. We propose that sensitization campaigns be carried out to educate inhabitants on the rich biodiversity of Kedjom Keku forest and explain to them the importance of sustainable management of the resources therein.
\end{abstract}




\section{Keywords}

Cameroon, Plant Diversity, Anthropogenic Activities, Land Use, Land Cover

\section{Introduction}

Conservation of natural forests and their resources is important in climate change mitigation. However, effective conservation strategies require an understanding of tree species composition and knowledge of the forest stand structure, which will permit the drawing up of a good forest conservation plan [1]. Tropical rain forests are valuable ecosystems and are amongst the most species-rich biome of the world [2]. They harbor over $50 \%$ of species on just $7 \%$ of the land area [3] with enormous wealth of animals such as insects, amphibians, reptiles, mammals and birds [4]. Ninety percent of primates and $80 \%$ of all known insects are found in the tropical rain forests [5]. One hectare of primary forest usually contains about 100 - 500 tree species with individual girths exceeding 10 $\mathrm{cm}$ [6]. Over 800 million people depend on tropical forests for fuel, food, and income [7]. For these reasons, tropical forests are undergoing rapid land use changes, including deforestation, as a result of agricultural expansion, commercial logging, plantation development, mining, industry, urbanization, and road building amongst other uses [7] [8] [9].

Cameroon is ranked fourth in Africa for her rich biodiversity [10] and often described as Africa in miniature [11]. Forests cover about 48\% of Cameroon's national territory, approximately 22,500,000 hectares [12]. Most of the forests form part of the Congo basin forest which is the second largest area of dense tropical forest in the world after the Amazon [13].

The Cameroonian forest has been divided into permanent and non-permanent forest estates by the Cameroon government. The permanent forests estates otherwise known as protected areas are considered to be areas belonging to the state [14]. Despite these efforts invested by the administration to protect the forests and its related resources, deforestation has not ceased in both protected and non-protected areas, leading to a continuous change in forest cover and land use. It is estimated that the legal rate of forest change in Cameroon between 2000 and 2005 was $-1 \%$ to $-1.5 \%$ per year [15] meanwhile it was $-0.9 \%$ for the period 1990-2000 [16].

The natural habitat of the Cameroonian Highlands is composed of sub-montane and afromontane forests, with subalpine grasslands on the highest peaks [17]. The Bamenda Highlands is the most diverse and important area in the Cameroon highlands after Mt. Cameroon and Mt. Kupé [4]. Several taxa are endemic to the Bamenda Highlands [17] and particularly to its highest peak at Mt Oku [18]. These highlands are well-known for their richness in plant species diversity, with limited documented works carried out at Kedjom Keku forest which is one of the Bamenda Highlands forest. However, preliminary plant surveys along- 
side bird surveys conducted revealed that this forest falls amongst the 34 global hotspots [19] and the 218 endemic bird areas [20].

Although these highlands are areas of high endemism and a biodiversity hotspot, the conflicting goal between increase production and sustainable resource management is a call for concern. The high level of anthropomorphic pressure has resulted to savannization of the tropical montane cloud forests [21] and a dramatic decreasing of biodiversity. The aim of this research was therefore to assess the plant species composition; diversity and analysis of forest cover change in the Kedjom Keku Community forest. The findings are expected to help orient government policies in the management plan of the Kedjom Keku Montane Forest.

\section{Materials and Methods}

\subsection{Location of Study Area}

The Kedjom Keku forest is a fragmented misty montane forest situated in Kedjom Keku village, in Tubah Sub-division, of Mezam division in the North West region of Cameroon. Tubah sub division is located in latitude $4^{\circ} 50^{\prime}-5^{\circ} 20^{\prime} \mathrm{N}$ and longitude $10^{\circ} 35^{\prime}-11^{\circ} 59^{\prime} \mathrm{E}$ with an altitude of $950-1500 \mathrm{~m} \mathrm{[22]}$. The climate is characterized by two seasons: a dry season in November-April, and a rainy season in May-October. The mean amount of rainfall per annum ranges from 1780 - $2290 \mathrm{~mm}$, temperature is between $15^{\circ} \mathrm{C}-32^{\circ} \mathrm{C}$ [23], with a relative humidity above $86 \%$ throughout the year [24]. The vegetation is primarily grassland savannah but a forested area of about 386.50 ha is found in Kedjom Keku, where this study was carried out.

\subsection{Plant Diversity Assessment}

The Kedjom Keku forest is fragmented into three different forest patches (Kefem, Kubuh, and Abonghen) separated by fields of grasslands and linked together by forest corridors [4]. The forest community of Keffem is divided into three sub forest patches comprising of Kubuh (2105 - 2155 m), Medong I (1801 $1900 \mathrm{~m}$ ), and Medong II (1965 - $1995 \mathrm{~m}$ ), while Abonghen is divided into Abonghen up (1835 - $1885 \mathrm{~m}$ ) and Abonghen down (1982 - $2001 \mathrm{~m}$ ).

A reconnaissance survey was carried out in June 2017 to obtain basic information, get acquainted with the forest, and to select the appropriate sites to lay plots for this study. The selection of plots for vegetation assessment was guided by physical and human factors such as; climate (rainfall), altitude, slope, soil and the degree of forest use. At least one plot was laid in each of the forest fragments. Small rectangular sampling plots of $10 \mathrm{~m} \times 10 \mathrm{~m}$ were established at irregular intervals $(50 \mathrm{~m} \times 100 \mathrm{~m})$ along a line transect or from a random starting point and plants were sampled, following the method described in [25], both within and at the edge of the forest in order to collect quantitative data.

All trees, shrubs and lianas with diameter at breast height $(\mathrm{DBH}) \geq 10 \mathrm{~mm}$ were noted and DBH measured at $1.3 \mathrm{~m}$ from the ground level. Plant specimens 
were collected, identified and the identification was confirmed at the National Herbarium of Cameroon (YA) in Yaoundé. Plant identification was carried out with the aid of textbooks such as, the Flora of Cameroon [26] [27], Flora of West Tropical Africa [28], and others [29] [30]. Identification was done to the level of the genus and to species where possible. Vouchers of the specimens have been deposited at the Limbe Botanic Garden herbarium.

\subsection{Evaluating Land Use/Land Cover Changes in the Kedjom Keku Forest}

This was done by the use of high resolution satellite images following the method described in [31]. The satellite data was made up of three years multi temporal satellite images (LANDSAT 5 TM images of 1986, Landsat 7 ETM+ images of 2003 and Landsat 8 OLI images of 2018) for the month of February obtained from the United States Geological Survey (USGS) GLOVIS website. A total of three satellite images were therefore downloaded with a resolution of 30 $m$ with less than $5 \%$ cloud cover and track numbers of 186/56 and 200/56.

In the pre-processing of the data, the level $1 \mathrm{~T}(\mathrm{~L} 1 \mathrm{~T})$ data products were provided systematic radiometric and geometric corrections by incorporating ground control points (GCPs) with the aid of Geographical Positioning System (GPS), while also employing a digital elevation model (DEM) to undertake terrain correction. Image processing used the UTM WGS84 (50) projection system and corrected for terrain relief. For GIS analysis, ArcGIS 9.0 software was used [31].

\subsection{Investigating Anthropogenic Activities}

Semi-structured questionnaires were used to evaluate the reasons for degradation in the last ten years. A total of 100 questionnaires were administered to some randomly selected local groups, and individuals of the four villages (Bambui, Kedjom Keku, Kedjom Ketingo and Finge) that immediately surround the Kedjom Keku forest. Twenty five questionnaires were administered per village. The questionnaires were designed such that the gender, age, educational qualifications, marital status and the different opinions of the respondents on the biodiversity of the Kedjom Keku forest were captured.

\subsection{Data Analysis}

\subsubsection{Plant Diversity}

Density, frequency, abundance, dominance and importance value index (IVI) of the plant species were analyzed following the procedures described in [32].

The importance value index was a summation of the relative frequency, relative density and relative dominance [32].

The diversity index of the species was analyzed using the Shannon Wiener diversity index [33] where; $H^{\prime}=-\sum\left(n_{i} / N\right) \ln n i / N$ and $H^{\prime}=$ Shannon-Wiener index of diversity, $n_{i}=$ the importance value index of the $t^{\text {th }}$ species, $N=$ sum of the importance value index of all the species. 
Sørensen's index [34] was used to calculate the species distribution and similarities within the different sampled plots $Q S=|\operatorname{frac}\{2 \mathrm{C}\}\{\mathrm{A}+\mathrm{B}\}=|$ frac $\{2|\mathrm{~A}|$ cap $B \mid\}\{|A|+|B|\}$ where $A$ and $B$ are the number of species in samples $A$ and $B$, respectively, and $C$ is the number of species shared by the two samples; QS is the quotient of similarity and ranges from 0 to 1 .

\subsubsection{Land Use Land Cover (LULC) Classification}

Change detection procedures including normalized difference vegetation index (NDVI) and supervised classification (maximum likelihood method) using all the spectra bands in the three Landsat images were used for the characterization and understanding of the land-use-land cover changes [35]. The images of the study area were taken through three stages to generate land cover classes of the study area. These included: 1) feature extraction; 2) selection of training data (signatures); and 3) selection of suitable classification approaches.

The NDVI classification scheme was used to identify the different vegetation types in the area and subsequently the patterns of change. Spectral signatures were collected from specified locations (1:36 at each degree latitude and longitude intersect) by digitizing various polygons overlaying the different land use types [36] [37].

The images were overlaid and a transition matrix prepared for the overlaid maps of the reference years. The following seven land cover and use classes were identified and mapped: dense vegetation, bare surface (roads), grassland, farm land, sparse vegetation, rocky terrain and settlements. The image classification was guided by reconnaissance information gathered from the field of the study area.

\subsubsection{Anthropogenic Activities}

Basic descriptive statistics using Microsoft excel version 2007, were used to transform the data into relative forms of percentages.

\section{Results}

A total of 1786 individual trees, 283 shrubs and 11 lianas were sampled. They belonged to 107 plant species, including 74 trees, 28 shrubs and 5 lianas, with a great number of species constituting the understory (Table 1 and Table 2). About $98 \%$ of them were identified to the level of species, while the remaining $2 \%$ were identified to genus.

\subsection{Tree Species Composition}

The 74 tree species belonged to 60 genera and 37 families. Albizia, Canthium, Ficus, and Psychotria were the most represented genera with 3 species each. The most represented family was Rubiaceae with 10 species, while the least represented families were Amaryllidaceae, Annonaceae, Bombacaceae, Caesalpiniaceae, Cannabaceae, Caricaceae, Cluciaceae, Compositae, Hypericaceae, Loganiaceae, Menispermaceae, Monimiaceae, Myristicaceae, Myrsinaceae, Myrtaceae, 
Pandaceae, Phyllanthaceae, Primulaceae, Rosaceae, Salicaceae, Stilbaceae, Thymelaeaceae with 1 species each (Table 1 ).

The tree species with the highest number of individuals was Xylopia africana with relative abundance of 55, while the tree species with the lowest species abundance were Bersama abyssinica, Blighia africana, Chitratus gilitii, Ficus toninguii, Garcinia staudii, Ocimum sp, Ocimum canuum, Pearsia americana, Shiracopsis elipticum, and Zanthozylum hexi all with relative abundances of 1.00 each (Table 1).

The basal area for all the different tree species ranged from a lower value of $78.54 \mathrm{~cm}^{2} \cdot \mathrm{ha}^{-1}$ as observed with Xymalos monospora to the highest value of $69181.25 \mathrm{~cm}^{2} \cdot \mathrm{ha}^{-1}$ observed with Schefflera mannii. The total basal area of all the tree species was $232343.43 \mathrm{~cm}^{2} \cdot \mathrm{ha}^{-1}$ (Table 1 ).

The total stem density for trees was 357.2 individual's ha ${ }^{-1}$. The species with the highest stem density was Maesa lanceolate with 47.4 individual's ha $^{-1}$ while the species with lowest stem density were Bersama abyssinica, Blighia africana, Chitratus gilitii, Ficus toninguii, Garcinia staudi, Ocimum canuum, Ocimum sp, Pearsia americana and Zanthozylum hexi with 0.2 individual's ha ${ }^{-1}$ (Table 1).

Tree species with the highest importance value index (IVI) was Schefflera manii (31.9), while Blighia africana recorded the lowest importance value index of 0.153. Thus, Schefflera mannii was the most ecologically important tree species in this forest.

\subsection{Shrub Species Composition}

Shrub species belonged to 25 genera and 17 families, with most of the shrubs belonging to the Asteraceae ( 5 species) (Table 2). The shrub species with the highest number of individuals was Calyx gamosepalous with relative abundance of 9.5, while the shrub species with the lowest relative abundances were Datura $s p$ and Perperomia pellucida with relative abundances of 1.00 each (Table 2).

The basal area for all the different shrub species in the study ranged from a lower value of $54.11 \mathrm{~cm}^{2} \cdot \mathrm{ha}^{-1}$ as observed with Sida acuta to a higher value of $1017.88 \mathrm{~cm}^{2} \cdot \mathrm{ha}^{-1}$ for Vernonia conferta. The total basal area of all the shrubs species was $5310.74 \mathrm{~cm}^{2} \cdot \mathrm{ha}^{-1}$ (Table 2).

The total stem density for shrubs was 57.4 individual's ha ${ }^{-1}$. Trema orientalis had the highest stem density of 5.8 individual's ha $^{-1}$, while the lowest stem density of 0.4 individual's ha ${ }^{-1}$ was recorded with Peperomia pellucida, Vernonia amygdalina, and Cleistopholis glauca (Table 2).

Uraria picta was the shrub species with the highest ecological importance with an importance value index of 23.36, while the least important species was Peperomia pellucida (3.02) (Table 2).

\subsection{Liana Species Composition}

Five lianas species were identified within the forest; Dioscorea smilacifolia, Dioscorea sp, Salacia longipes, Strychnos sp and Gouania longipetala with relative abundances of $1.33,1.50,0.66,1.21$ and 1.00 respectively. 
Table 1. Composition of tree species in Kedjom Keku forest.

\begin{tabular}{|c|c|c|c|c|c|c|}
\hline Family & Species Name (Author) & Rel. Abun & $\begin{array}{l}\text { Basal Area } \\
\left(\mathrm{cm}^{2} \cdot \mathrm{ha}^{-1}\right)\end{array}$ & $\mathbf{R F}$ & $\begin{array}{c}\text { Density } \\
\left(\mathrm{ha}^{-1}\right)\end{array}$ & IVI \\
\hline Annonaceae & Xylopia africana (Benth.) Oliv & 55 & 89.25 & 0.61 & 2.2 & 1.27 \\
\hline Apocynaceae & Picralima nitida (Stapf) T. Durand & 8 & 176.71 & 0.11 & 2.8 & 0.30 \\
\hline \multirow{2}{*}{ Araliaceae } & Polyscias fulva (Heirn) Harms & 31.75 & 2292.77 & 7.11 & 25.4 & 15.21 \\
\hline & Schefflera mannii (Hook f.) Harms & 4.75 & 69181.25 & 1.06 & 3.8 & 31.91 \\
\hline Cannabaceae & Celtis zenkeri Engl & 5.67 & 165.13 & 0.17 & 3.4 & 0.41 \\
\hline Caricaceae & Cylicomorpha solmsii (Urb.) Urb & 6.67 & 95.03 & 0.11 & 4 & 0.27 \\
\hline \multirow{2}{*}{ Celastraceae } & Salicia satudiana Loes (Wilczek) N. Hallé & 1.25 & 741.68 & 0.28 & 1 & 0.88 \\
\hline & Salicia staudii (Wilczek) N. Hallé & 2 & 13892.91 & 0.11 & 0.4 & 6.21 \\
\hline \multirow[t]{2}{*}{ Clusiaceae } & Garcinia staudtii Engl & 1 & 1734.94 & 0.51 & 0.2 & 1.76 \\
\hline & Croton macrostachyus Hochst. Ex Hochst & 13.2 & 1801.27 & 1.12 & 13.2 & 3.02 \\
\hline \multirow[t]{4}{*}{ Euphorbiaceae } & Euphobia desmindi Keay \& Miline-Redhead & 11 & 113.10 & 0.22 & 2.2 & 0.49 \\
\hline & Macaranga occidentalis Mull. Arg & 8 & 254.47 & 1.34 & 4.8 & 2.79 \\
\hline & Albizia adianthifolia (Schumach.W. Wight) & 13 & 5999.47 & 2.18 & 7.8 & 6.94 \\
\hline & Albizia sp (Schumach.W.F Wight) & 4 & 26158.67 & 0.23 & 0.8 & 11.71 \\
\hline \multirow{4}{*}{ Fabaceae } & Albizia zygia (J.F.Macbr) & 6.25 & 3752.30 & 1.40 & 5 & 4.42 \\
\hline & Dialium lopens Brateler & 2 & 1164.16 & 0.33 & 0.4 & 1.17 \\
\hline & Dipteryx alata Vogel & 3 & 891.97 & 0.28 & 1.2 & 0.94 \\
\hline & Piptadeniastrum africanum (Hook.F.) Brenan & 6.75 & 86.59 & 1.51 & 5.4 & 3.06 \\
\hline \multirow{2}{*}{ Francoaceae } & Bersama abyssinica (Gürke) F. White Fresen & 1 & 176.71 & 0.05 & 0.2 & 0.19 \\
\hline & Bersama engleriana (Gürke) F. White & 2 & 165.13 & 0.11 & 0.4 & 0.29 \\
\hline \multirow[t]{2}{*}{ Lamiaceae } & Ocimum sp (L.) Benth & 1 & 615.75 & 0.05 & 0.2 & 0.37 \\
\hline & Cinnadenia paniculata (Hook.F.) Kosterm. & 6 & 340.12 & 0.67 & 2.4 & 1.49 \\
\hline \multirow[t]{2}{*}{ Lauraceae } & Litsea auriculata Chien \& Cheng & 2.33 & 153.94 & 0.39 & 1.4 & 0.85 \\
\hline & Persia americana Mill. & 1 & 1809.56 & 0.05 & 0.2 & 0.89 \\
\hline \multirow[t]{2}{*}{ Loganiaceae } & Strychnos staudtii Gilg & 25.33 & 855.30 & 1.12 & 15.2 & 2.61 \\
\hline & $\underline{B o m b a x}$ anceps Pierre & 1 & 1590.43 & 0.11 & 0.4 & 0.91 \\
\hline \multirow{3}{*}{ Malvaceae } & Bombax buonopozense P. Beauv & 5 & 3631.68 & 4.08 & 1 & 9.74 \\
\hline & Ceiba pentandra (Thonn.) A. Chev & 8 & 1734.94 & 0.89 & 3.2 & 2.54 \\
\hline & Cola verticillata (Thonn.) Stapf. Ex. A.cher & 1.5 & 804.25 & 0.17 & 0.6 & 0.68 \\
\hline Malvaceae & Rhodognaphalon brevicuspe (Sprague) Roberty & 25 & 113.10 & 0.28 & 1 & 0.61 \\
\hline \multirow{2}{*}{ Meliaceae } & Carapa grandiflora Sprague & 4.6 & 681.64 & 1.29 & 4.6 & 2.87 \\
\hline & Trichilia rubescens Oliv & 3 & 551.55 & 0.28 & 0.6 & 0.79 \\
\hline Menispermaceae & Penianthus camerounensis A.Dekker & 3.33 & 95.03 & 0.56 & 2 & 1.16 \\
\hline \multirow[t]{3}{*}{ Monimiaceae } & Xymalos monospora (Harv.) Baill. & 1.67 & 78.54 & 0.28 & 1 & 0.59 \\
\hline & Antiaris toxicaria (Lesch) & 4.5 & 4778.36 & 0.51 & 1.8 & 3.06 \\
\hline & Ficus asperifolia Hook ex Miq & 4 & 4536.46 & 0.11 & 0.8 & 2.17 \\
\hline \multirow[t]{3}{*}{ Moraceae } & Ficus $s p$ & 2 & 32576.27 & 0.05 & 0.4 & 14.13 \\
\hline & Ficus thonningii Blume & 1 & 176.71 & 0.05 & 0.2 & 0.19 \\
\hline & Treculia africana Decne. ex Trec & 24.33 & 4359.16 & 0.78 & 14.6 & 3.44 \\
\hline
\end{tabular}




\section{Continued}

\begin{tabular}{|c|c|c|c|c|c|c|}
\hline Myristicaceae & Pycnanthus angolensis (Welw,) Warb. & 4.33 & 380.13 & 0.73 & 2.6 & 1.62 \\
\hline Myrtaceae & Eucalyptus globules Labill. & 5 & 3382.94 & 0.62 & 1 & 2.69 \\
\hline Olacaceae & Strombosia grandifolia Hook.F. & 3 & 600.02 & 4.25 & 1.2 & 8.77 \\
\hline Oleaceae & Olea capensis Linn. & 19 & 4630.05 & 5.31 & 19 & 12.63 \\
\hline Pandaceae & Microdesmis zenkeri $\mathrm{Pax}$ & 11.67 & 183.85 & 1.96 & 7 & 3.99 \\
\hline Passifloraceae & $\begin{array}{l}\text { Barteria fistulosa Waterman, P.G., Ross, J.A.M. \& } \\
\text { McKey, D.B Mast }\end{array}$ & 1.5 & 2632.98 & 0.34 & 1.2 & 1.81 \\
\hline Phyllanthaceae & Bridalia micrantha (Hochst) Baill & 12.2 & 1464.38 & 3.45 & 12.2 & 7.46 \\
\hline \multirow{2}{*}{ Pittosporaceae } & Pittosporum manii Hook.f & 15 & 1306.12 & 0.16 & 0.6 & 0.89 \\
\hline & Pittosporum $s p$ & 29.25 & 637.94 & 6.55 & 23.4 & 13.38 \\
\hline Primulaceae & Maesa lanceolata Forssk & 47.4 & 871.44 & 13.27 & 47.4 & 26.92 \\
\hline Rosaceae & Prunus africana (Hook.f.) Kalkman. & 4.75 & 1438.72 & 1.06 & 3.8 & 2.75 \\
\hline \multirow{10}{*}{ Rubiaceae } & $\begin{array}{l}\text { Aidia micrantha } \\
\text { (K. Schum.) Bullock ex F. White }\end{array}$ & 3 & 132.73 & 0.51 & 1.8 & 1.06 \\
\hline & Aoranthe cladantha (K. Schum.) Somers & 45 & 219.56 & 0.51 & 1.8 & 1.11 \\
\hline & Brenania brieyi (De Wild.) Petit & 10 & 908.99 & 0.95 & 4 & 2.29 \\
\hline & Canthium acutiflorum Merr. ed. F & 6 & 196.81 & 0.33 & 1.2 & 0.76 \\
\hline & Canthium manii Hiern & 7.33 & 1755.68 & 1.23 & 4.4 & 3.22 \\
\hline & Canthium subcordatum Burkill, H.M & 9.75 & 957.17 & 2.18 & 7.8 & 4.78 \\
\hline & Coffea charrieriana Stof \& F. Anthony & 4 & 522.79 & 0.22 & 0.8 & 0.67 \\
\hline & Psychotria angolensis (Welw.) Warb & 29.5 & 704.97 & 3.30 & 11.8 & 6.91 \\
\hline & Psychotria peduncularis (Salisb) Steyerm & 6.2 & 314.16 & 1.73 & 6.2 & 3.61 \\
\hline & Psychotria strictistipula Schnell. & 9.5 & 333.94 & 2.13 & 7.6 & 4.39 \\
\hline \multirow{4}{*}{ Rutaceae } & Araliopsis tabouensis Aubrev \&Pellegr & 14 & 1359.83 & 2.35 & 8.4 & 5.29 \\
\hline & Clausena anisata (Wild) Hook. F. ex Benth & 6.8 & 244.95 & 1.91 & 6.8 & 3.91 \\
\hline & Zanthoxylum gilleti (De Wild.) P.G Waterman & 2 & 113.10 & 0.11 & 0.4 & 0.27 \\
\hline & Zanthoxylum heitzii (Aubreis \& Pellegr) P.G Waterm. & 1 & 637.94 & 0.05 & 0.2 & 0.39 \\
\hline Salicaceae & Oncoba mannii Oliv & 3 & 132.73 & 0.50 & 1.8 & 1.07 \\
\hline \multirow{2}{*}{ Sapindaceae } & Allophylus bullatus (Radlk) & 9.2 & 2280.90 & 2.57 & 9.2 & 6.13 \\
\hline & Blighia africana $\underline{\text { K. D. Koenig }}$ & 1 & 95.03 & 0.05 & 0.2 & 0.15 \\
\hline \multirow{2}{*}{ Sapindaceae } & Blighia sapida K. D. Koenig & 12.75 & 249.69 & 2.85 & 10.2 & 5.828 \\
\hline & Chytranthus gilletii De Wild & 1 & 314.16 & 0.05 & 0.2 & 0.25 \\
\hline Sterculiaceae & Sterculiar tragacantha Lindl & 2 & 598.28 & 0.33 & 0.4 & 0.93 \\
\hline Stilbaceae & Nuxia congesta R. Br. ex Fresen. & 16.5 & 10071.39 & 3.69 & 13.2 & 11.73 \\
\hline Thymelaeaceae & Gnidia glauca (Fresen.) Gilg & 2 & 2910.98 & 0.33 & 1.2 & 1.93 \\
\hline Tiliaceae & Glyphaea brevis (Spreng.) Monach & 3 & 811.81 & 3.69 & 1.8 & 7.74 \\
\hline \multirow[t]{2}{*}{ Ulmaceae } & Phyllostylon brasiliense Capan. ex Benth. \& Hook.f. & 1 & 530.93 & 0.05 & 0.2 & 0.34 \\
\hline & & & 232343.43 & 100.00 & 357.2 & 300.00 \\
\hline
\end{tabular}

Rel. Abun.: Relative Abundance, RF: Relative Frequency, IVI: Importance Value Index. 
Table 2. Composition of shrubs in the Kedjom Keku forest.

\begin{tabular}{|c|c|c|c|c|c|c|}
\hline Family & Species Name (Author) & Rel Abun & $\begin{array}{l}\text { Basal Area } \\
\left(\mathrm{cm}^{2} \mathrm{ha}^{-1}\right)\end{array}$ & RF & Density & IVI \\
\hline \multirow{2}{*}{ Acanthaceae } & Brillantaisia lamium (Nees) Benth. & 6.2 & 78.54 & 8.71 & 5 & 18.90 \\
\hline & Justicia insularis (T. Anders.) & 4.67 & 111.22 & 4.87 & 2.8 & 11.85 \\
\hline Anonnaceae & Cleistopholis glauca Pierre ex Engl. \& Diels & 5 & 201.06 & 1.74 & 0.4 & 7.27 \\
\hline \multirow{2}{*}{ Apocynaceae } & Voacanga africana Stapf & 5.67 & 113.10 & 5.92 & 3.4 & 13.97 \\
\hline & Rauvolfia vomitoria Afzel & 2.3 & 188.69 & 2.44 & 1.4 & 8.43 \\
\hline \multirow{5}{*}{ Asteraceae } & Crassocephalum manii (Hook.f.) Milne-Redh & 7.5 & 78.54 & 4.87 & 1 & 11.24 \\
\hline & Solanecio mannii (Hook.f.).Jeffrey & 7 & 132.73 & 4.87 & 2.8 & 12.26 \\
\hline & Symphyotrichum cordifolium (L.) G. L. Nesom & 3 & 124.69 & 2.09 & 1.8 & 6.53 \\
\hline & Vernonia amygdalina Delile & 3 & 365.42 & 3.14 & 0.4 & 13.15 \\
\hline & Vernonia conferta Benth & 2 & 1017.88 & 0.69 & 3.8 & 20.56 \\
\hline Balsaminaceae & Impatiens disotis Hooker F. & 1.3 & 201.06 & 1.39 & 0.8 & 6.57 \\
\hline Begoniaceae & Chytranthus tolbotii Baker F. Keay & 2.5 & 176.71 & 1.74 & 1 & 6.81 \\
\hline Campanulaceae & Lobelia columinaris Hook. F & 4.8 & 100.29 & 8.36 & 4.8 & 18.61 \\
\hline Cannabaceae & Trema orientalis (L.) Blume & 3.5 & 95.03 & 2.44 & 5.8 & 6.67 \\
\hline Euphorbiaceae & Mallatotus oppositifolius (Geiseler) Müll.Arg. & 6 & 86.59 & 4.18 & 2.4 & 9.99 \\
\hline \multirow{2}{*}{ Fabaceae } & Calyx gamosepalous Lychnis & 9.5 & 132.73 & 6.62 & 1.4 & 15.74 \\
\hline & Uraria picta Jacq. & 5.8 & 167.42 & 10.11 & 1.2 & 23.36 \\
\hline \multirow[t]{2}{*}{ Malvaceae } & Sida acuta Burm. F. & 6.5 & 54.11 & 4.53 & 2.6 & 10.08 \\
\hline & Peperomia pellucida Kunth. & 1 & 86.59 & 0.69 & 0.4 & 3.02 \\
\hline \multirow[t]{2}{*}{ Piperaceae } & Peperomia vulcanica Baker \& C. H Wright & 3 & 95.03 & 1.05 & 0.6 & 3.88 \\
\hline & Piper capense Linn. & 2 & 119.79 & 7.32 & 0.8 & 16.89 \\
\hline Rhamnaceae & Gouania longipetala Hemsl & 1.5 & 201.06 & 1.05 & 0.6 & 5.87 \\
\hline Rubiaceae & Psydrax arnoldiana De Wild. \& T. Durand & 4.2 & 106.60 & 1.39 & 4.2 & 4.79 \\
\hline \multirow[t]{2}{*}{ Sapindaceae } & Xerospermum noronhianum Blume (Blume) & 3 & 103.87 & 2.09 & 1.2 & 6.14 \\
\hline & Datura $s p$ Linn. & 1 & 165.13 & 0.69 & 2.8 & 4.50 \\
\hline \multirow[t]{2}{*}{ Solanaceae } & Solanum betaceum Cav. & 1.5 & 572.56 & 1.05 & 0.6 & 12.87 \\
\hline & Solanum incanum Linn. & 9 & 257.59 & 3.14 & 1.8 & 11.12 \\
\hline \multirow[t]{2}{*}{ Violaceae } & Rinorea oblongifolia C.H. Wright & 4 & 176.71 & 2.78 & 1.6 & 8.90 \\
\hline & & & 5310.74 & 100 & 57.4 & 300 \\
\hline
\end{tabular}

*Rel. Abun.: Relatıve Abundance, RF: Relative Frequency, IVI: Importance Value Index.

\subsection{Diameter Class Distribution of Species in the Kedjom Keku Forest}

The size class (depth at breast height) distribution for trees sampled in the forest exhibited a reverse J-shaped distribution, indicating that the population of both trees and shrubs were skewed towards younger trees and younger shrubs. Most of the trees sampled had a dbh ranging from $10-30 \mathrm{~cm}$, while the $\mathrm{dbh}$ for 
shrubs ranged from $10-15 \mathrm{~cm}$.

Stand density and species richness for trees decreased with an increase in the stem size class of the trees (Table 3). The lowest size class of $10-30 \mathrm{~cm}$ captured $49.38 \%$ of stand density and $49.31 \%$ of species richness in all the trees sampled in the forest. The basal area did not consistently reduce as dbh size class increased. The lowest size class of $10-30 \mathrm{~cm}$ had the highest basal area of $108183.53 \mathrm{~m}^{2} \cdot \mathrm{ha}^{-1}$ followed by the third size class of $50-70 \mathrm{~cm}$ with basal area of $73115.09 \mathrm{~m}^{2} \cdot \mathrm{ha}^{-1}$ which over shadows the second size class of $30-50 \mathrm{~cm}$, with a percentage difference of $28.87 \%$ (Table 3 ).

Species richness and stand density of shrubs in the Kedjom Keku forest decreased as diameter size class increased (Table 4). Density decreased from 49 to 0.4 individual's ha $^{-1}$ with an increase in size of shrub. Similar pattern was observed with species richness, which decreased from 39.76 - 0.18 (Table 4). In each size class, forest stand density and species richness varied consistently together. The basal area also decreased as diameter size class increased (Table 4).

\subsection{Species Diversity}

Shannon-Wiener diversity index for trees was 3.56 and 3.07 for shrubs, while Simpson dominance index was 0.33 for trees and 0.27 for shrubs. Species evenness was 0.98 for trees and 0.74 for shrubs (Table 5).

\subsection{Evaluating the Land Use/Land Cover Area Changes in the Kedjom Keku Forest}

Supervised classification of the images yielded three land cover maps of the study area (Figures 1(a)-(c)). Seven LULC classes were identified after classification and they included; dense vegetation, bare surface (roads), grassland, farm land, sparse vegetation, rocky terrain, and build up settlements.

It was observed that dense vegetation decreased from 151.86 ha $(51.21 \%)$ in 1986 to 121 ha (40.79\%) in 2018. Most of the forest was destroyed from 1986-2003 (Figure 1(a), Figure 1(b)). There was a significant increase in built up settlement in the area, from 1.17 ha $(0.48 \%)$ in 1986 to 60.75 ha $(20.46 \%)$ in 2018 , with a lot more settlements built from 2003-2018. The loss in dense vegetation was replaced by grassland, which increased from $3.18 \%$ in 1986 to $11.56 \%$ in

Table 3. Basal area, stand density and species richness for different stem size class of trees in Kedjom Keku forest.

\begin{tabular}{cccc}
\hline DBH size $(\mathrm{cm})$ & $\begin{array}{c}\text { Basal area } \\
\left(\mathrm{m}^{2} \cdot \mathrm{ha}^{-1}\right)\end{array}$ & $\begin{array}{c}\text { Density } \\
\left(\mathrm{ha}^{-1}\right)\end{array}$ & Species richness \\
\hline $10-30$ & 108183.53 & 176.4 & 112.73 \\
$30-50$ & 40355.49 & 127.2 & 82.41 \\
$50-70$ & 73115.09 & 26 & 16.43 \\
$70-90$ & 9616.51 & 22.4 & 14.29 \\
$>90$ & 1072.77 & 5.2 & 2.81 \\
\hline
\end{tabular}


Table 4. Basal area, stand density and species richness for different stem size class of shrubs in the Kedjom Keku forest.

\begin{tabular}{cccc}
\hline DBH size $(\mathrm{cm})$ & $\begin{array}{c}\text { Basal area } \\
\left(\mathrm{m}^{2} \cdot \mathrm{ha}^{-1}\right)\end{array}$ & $\begin{array}{c}\text { Density } \\
\left(\mathrm{ha}^{-1}\right)\end{array}$ & Species Richness \\
\hline $10-15$ & 2305.42 & 49 & 39.76 \\
$15-20$ & 1049.46 & 5.6 & 4.06 \\
$20-25$ & 365.42 & 1.8 & 1.41 \\
$25-30$ & 572.5 & 0.6 & 0.35 \\
$>30$ & 1017.88 & 0.4 & 0.18 \\
\hline
\end{tabular}

Table 5. Characteristics of trees and shrubs in Kedjom Keku.

\begin{tabular}{ccc}
\hline Parameter & Trees & Shrubs \\
\hline Shannon Weiner Index $\left(H^{p}\right)$ & 3.56 & 3.07 \\
Pielou Evenness Index $\left(\mathrm{J}_{\mathrm{sw}}\right)$ & 0.98 & 0.74 \\
Simpson index $(\mathrm{Cd})$ & 0.33 & 0.27 \\
Species Richness & 78 & 28 \\
\hline
\end{tabular}
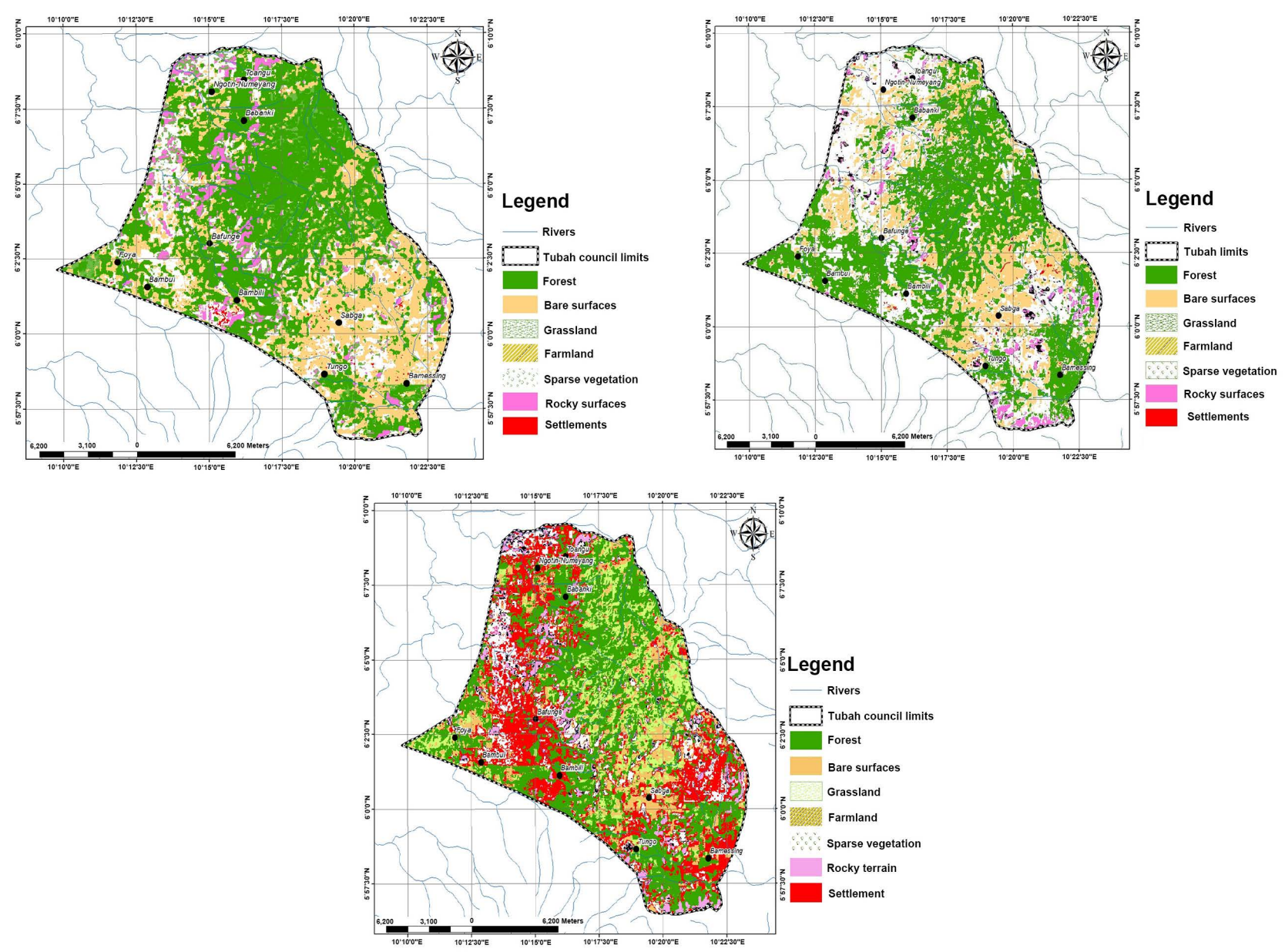

Figure 1. (a) 1986 LULC classified map of the Kedjom Keku forest; (b) 2003 LULC classified map of the Kedjom Keku forest; (c) 2018 LULC classified map of the Kedjom Keku forest. 
2018 (Table 6). Farmlands increased from 22.33 ha in 1986 to 47.76 ha in 2003; however these farmlands were later converted to build up settlements by 2018 , thus the observed decrease to 28.18 ha. As the built up settlement increased over the years, the grassland cover also increased, while bare surface and dense vegetation decreased (Table 6).

\subsection{Evaluating the Anthropogenic Activities within the Kedjom Keku Forest}

All the 100 questionnaires were completed, with most (60\%) of the respondents being female and $40 \%$ males. Forty eight percent of them were married, and their ages ranged from 18 - 51 and above, with over $80 \%$ of them being able to read and write. The demographics of the respondents are shown in Table 7.

Overall, $98 \%$ of the respondents recognized that the forest was being degraded. This was because the forest was exploited for economic reasons (60\%), which enabled the inhabitants of the environs to have fertile soil for food production, material for the construction of shelter etc. The respondents (14\%) were knowledgeable of the fact that the forest is an important water catchment area, $20 \%$ of them noted that it was a good source of medicine, and $6 \%$ agreed that it had socio-cultural value.

From their responses and from our observation in the field, agricultural activities (Figures 2(a)-(e)) were the major cause of forest degradation. These activities led to the creation of roads to facilitate evacuation of the farm produce, logging, collection of wood for fuel, building of settlements for farm workers and storage facilities. Forest were cleared to permit the cultivation of maize, beans, potatoes, carrot, garlic and many other food crops. The slash and burn method employed by the famers contributed to the degradation of this forest.

Other reasons which were stated as partly responsible for the degradation of the forest included; poverty, population growth and the need for more land for subsistence activities, inequitable distribution of land and resources as well as corruption.

In order to check further degradation, $20 \%$ of the respondents proposed that there should be concrete negotiations between the villagers and the conservationists so as to ensure a win-win partnership, $10 \%$ believed that clear demarcation

Table 6. Land use land cover changes in Kedjom Keku forest.

\begin{tabular}{ccccccc}
\hline Land use class & 1986 (ha) & $\%$ & 2003 (ha) & $\%$ & 2018 (ha) & $\%$ \\
\hline Dense vegetation & 151.86 & $51.21 \%$ & 119.88 & $45.4 \%$ & 121.12 & $40.79 \%$ \\
Bare surface & 83.94 & $28.31 \%$ & 62.56 & $23.72 \%$ & 36.79 & $12.39 \%$ \\
Grass land & 9.42 & $3.18 \%$ & 19.42 & $7.36 \%$ & 34.33 & $11.56 \%$ \\
Farmland & 22.33 & $7.53 \%$ & 47.76 & $18.11 \%$ & 28.18 & $9.49 \%$ \\
Sparse vegetation & 9.52 & $3.21 \%$ & 3.32 & $1.25 \%$ & 5.49 & $1.84 \%$ \\
Rocky terrain & 18.29 & $6.16 \%$ & 9.08 & $3.44 \%$ & 10.25 & $3.45 \%$ \\
Settlement/built up & 1.17 & $0.48 \%$ & 1.67 & $0.63 \%$ & 60.75 & $20.46 \%$ \\
\hline
\end{tabular}


Table 7. Demographic data of Respondents in the survey on anthropogenic activities linked to forest degradation in Kedjom Keku.

\begin{tabular}{|c|c|c|c|}
\hline Parameter & & Frequency & $\%$ Frequency \\
\hline \multirow{2}{*}{ Gender } & Male & 40 & 40 \\
\hline & Female & 60 & 60 \\
\hline \multirow{5}{*}{ Age Group } & $18-20$ & 10 & 10 \\
\hline & $21-30$ & 30 & 30 \\
\hline & $31-40$ & 30 & 30 \\
\hline & $41-50$ & 28 & 28 \\
\hline & 51 and above & 2 & 2 \\
\hline \multirow{4}{*}{ Marital Status } & Single & 32 & 32 \\
\hline & Married & 48 & 48 \\
\hline & Widow(er) & 14 & 14 \\
\hline & Divorcee & 6 & 6 \\
\hline \multirow{5}{*}{$\begin{array}{c}\text { Educational } \\
\text { Level }\end{array}$} & First School Leaving Certificate & 22 & 22 \\
\hline & General Certificate Examination-Ordinary Level & 22 & 22 \\
\hline & General Certificate Examination-Advanced Level & 28 & 28 \\
\hline & Degree holders & 14 & 14 \\
\hline & No formal education & 14 & 14 \\
\hline
\end{tabular}

of forest land was important, and $15 \%$ were of the opinion that the provision of alternative farm lands for the communities is inevitable. They all agreed that proper forest management plan that takes the need of the inhabitants into consideration will go a long way to minimize the degradation of this forest.

\section{Discussion}

\subsection{Flora Composition, Distribution and Diversity of Plant Species in the Kedjom Keku Forest}

The Bamenda Highlands is the most diverse and important area in the Cameroon highlands after Mt. Cameroon and Mt. Kupé [4]. These highlands are well-known for their richness in plant species diversity within the Kilum Ijim reserve and the Kedjom Keku forest. However, results from this study showed that despite the adverse degradation undergone by this forest, the flora of the Kedjom Keku forest still remains diverse. The $H^{p}$ value of 3.56 for trees obtained in this study area was within the range reported for other tropical forests in Central Africa sub-region [38].

The most represented tree family was the Rubiaceae and for shrubs was Solanaceae; this may be due to the high number of seeds produced by plants of these families within a specific fruiting season that tend to germinate producing new plants. This may also be as a result of edaphic and environmental factors that favour establishment of species. These families have species which may be better 

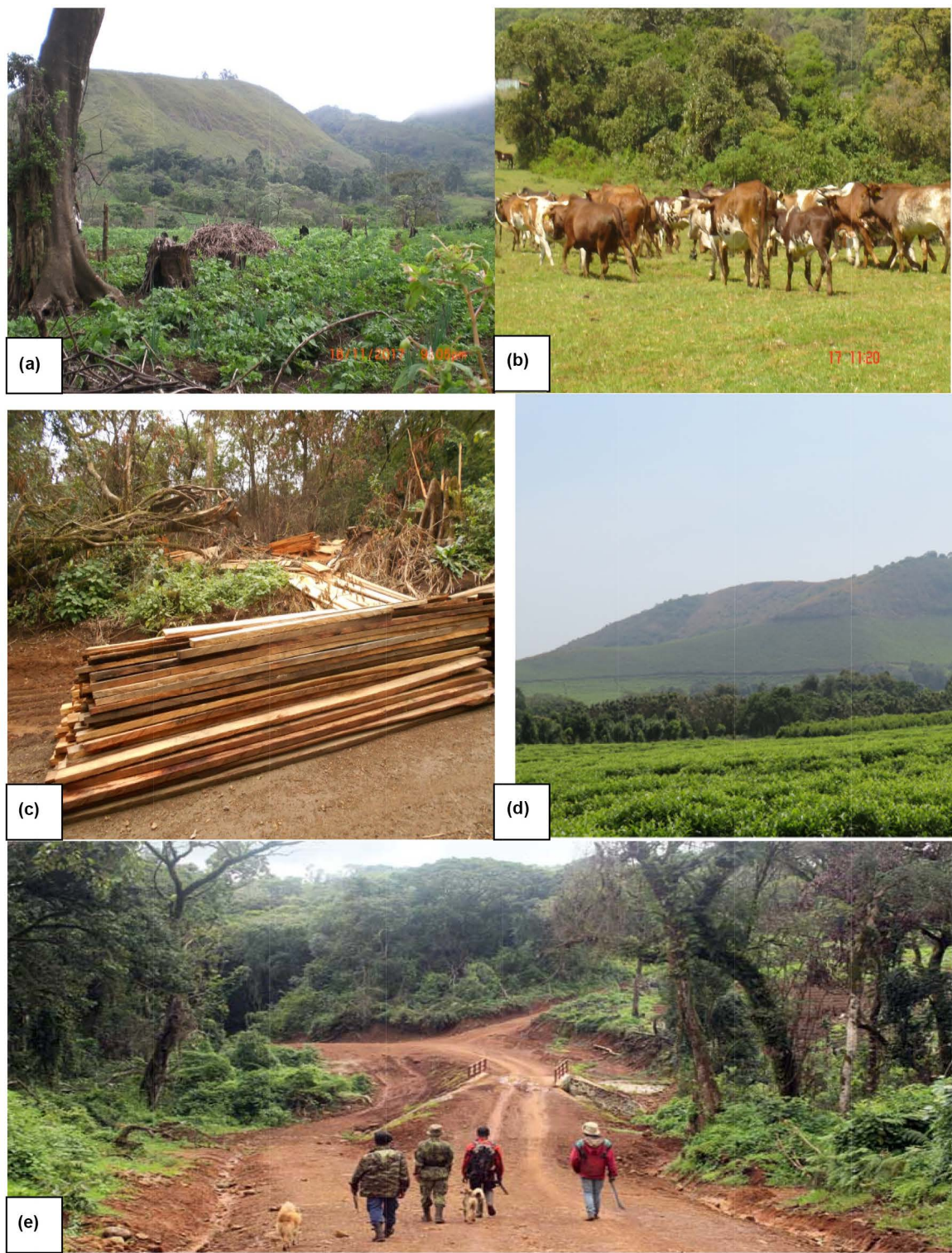

Figure 2. Anthropogenic activities which lead to degradation in Kedjom Keku forest; (a) Farming; (b) Grazing; (c) Logging; (d) Tea plantation; (e) Construction of bridges and roads.

competitors as they establish easily with fast growth rates. These results are in line with works conducted by [39] that assessed the vegetation structure and diversity of woody species in the mountain forest of Mt. Manengouba. He found that the four most important families in terms of density, diversity and dominance were Rubiaceae, Euphorbiaceae, Araliaceae and Myrsinaceae. These families represented $70.8 \%$ of the family important value in the forest. The result was also in line with the findings of [40] and [41] who reported that the Rubiaceae was the most dominant tree family in the Mount Cameroon region. It was also reported Rubiaceae to be the most dominant tree family in the Korup National Park [42], and another study [43] reported that the Rubiaceae was the most dominant tree family in the Azagny National Park of Cote D'Ivoire. Other re- 
searchers [44], found in natural regeneration forest in Korup National Park that soil nutrients played a major role in species richness and establishment in an ecosystem. The reasons for the poor establishment of some families which showed lowest species may be attributed to competition for nutrients, limited light by canopy trees and destruction of undergrowth during tree logging. The high level of anthropogenic activities occurring within this forest affects growth and distribution of species [45].

The total basal area of all the tree species was $232,343.43 \mathrm{~cm}^{2} \cdot \mathrm{ha}^{-1}$ with $S$ chefflera mannii recording the highest basal area while for shrubs; the highest basal area was $1017.88 \mathrm{~cm}^{2} \cdot \mathrm{ha}^{-1}$. The high basal area of tree species within the Kedjom Keku forest may be due to the presence of adapted root architecture to absorb nutrients for growth, as was observed in the Takamanda forest [46]. In the same light, in a study on forest composition and structure in three sites of a tropical forest, it was observed that shrub species recorded lower basal areas than those of tree species [47]. The low basal area could be attributed to poor root establishment for the acquisition of nutrients. Poor growth of tree species has been attributed to poor efficiency of some species in absorbing nutrients in the ecosystem [48].

Schefflera mannii (IVI of 31.9) and Maesa lanceolata (IVI of 26.9) were the species with the most ecological importance. $S$. mannii is noted to be vulnerable and threatened by habitat loss [49], thus, if appropriate conservation strategies are not put in place, this species may become extinct from this forest, especially with the LULC changes observed in this are over the years.

Stem diameter distributions within a forest may indicate the level and form of disturbance within the forests, in addition to providing insights into potential regeneration processes [6]. The stem size class distribution for both trees and shrubs in this study showed a reversed "J"-shaped curve or positively skewed, indicating that lower dbh classes are more abundant than might be expected in the flora population. Within the plots sampled, large trees $(>90 \mathrm{~cm} \mathrm{dbh})$ ranged from two to four species, and from one to nine individuals of each species. We found a larger number of species with dbh size class between $<10 \mathrm{~cm}>30 \mathrm{~cm}$ in both trees and shrubs.

A diversity index of 3.55 and 3.07 for tree and shrubs indicated the rich, diverse nature and the evenness of flora present within the Kedjom Keku forest. The rich diversity of this forest may be attributed to its natural state whereby this forest is still considered to be a primary forest with many of its natural nutrients. However, if measures are not taken, with the increase in anthropogenic activities, this observation may be different in a few years. Simpson's diversity index of trees (0.33) and shrubs (0.27) indicated a high diversity in the study area, an observation similar to the findings in India [50].

A measure of the equitability of species spread within the Kedjom Keku forest showed values of 0.97 and 0.74 for trees and shrubs respectively. This result is a proof that the flora of the Kedjom Keku forest is evenly distributed. Also, the Sorenson's similarity indexes for both trees and shrubs indicated that there do 
not exist much differences between the species found in the different plots sampled, hence species being evenly distributed.

\subsection{Land Use/Land Cover Changes in the Kedjom Keku Forest}

Forest clearance destroys the habitat and generally causes a decline in forest species abundance and diversity, particularly for species that are restricted in range. Diverse taxa show different and often variable responses [51]. The trend analysis of the Kedjom Keku forest reveals a change in size of the seven LULC features over 32 year period (1986-2018). This indicated that land use change has an effect on change in biodiversity in tropical forests [52]. The most pertinent situation found in these results is built-up/settlements which experienced the most positive geometric change from 2003 to 2018 with a high percentage from $0.98 \%$ to $20.46 \%$. This is partly as result of the high infrastructural activities going on in the whole of Tubah area, especially with the opening of the University of Bamenda in 2010, which harbors a great number of people. This has increased the construction of houses and motorable roads accessible for the population. As the fertile land degrades and reduce in its soil nutrients, people are forced to migrate to new areas, exploring new forest frontiers thus, and increasing deforestation. The results from this study also indicated that from 1986 to 2003, farmland, grassland and bare surface have increased thus, over the same period; dense vegetation, sparse vegetation, and rocky terrain decreased. Dense vegetation experienced an increase from 119.88 ha in 2003 to 121.12 ha in 2018, thus indicating that there have been some sensitization and conservation activities which are ongoing within the forest. The conversion of high dense vegetation to other LULC classes such as sparse vegetation and grassland is so prominent and promoted by the high degree of anthropogenic activities in this forest.

Population growth was a major cause for the observed land use, land cover changes. The rapid population growth in Tubah since 2010 was a major indirect and over-arching cause of deforestation. More people require more food and space which requires more land for agriculture and habitation. This in turn results in more clearing of forests.

\section{Conclusion}

The high level of anthropomorphic pressure, with a high rate of settlement areas in the recent years has reduced the forested area of Kedjom Keku, a phenomenon which if left unchecked may have adverse effects on the biodiversity of this forest. In spite of the high level of anthropogenic activities observed in this forest, it still harbors an enormous amount of floral diversity with Rubiaceae and Solanaceae being the most represented tree and shrub families respectively. There is therefore a need to modify the management plan to reflect present-day realities and to sensitize the population on the need to use the forest in a sustainable manner. The baseline information gathered in this study will guide plant species selection for any re-forestation project in the area. 


\section{Conflicts of Interest}

The authors declare no conflicts of interest regarding the publication of this paper.

\section{References}

[1] Aye, Y., Pampasit, S., Umponstira, C., et al. (2014) Floristic Composition, Diversity and Stand Structure of Tropical Forests in Popa Mountain Park. Journal of Environmental Protection, 5, 1588-1602. https://doi.org/10.4236/jep.2014.517150

[2] Hill, J.L. and Hill, R.A. (2001) Why Are Tropical Rain Forests So Species Rich? Classifying, Reviewing and Evaluating Theories. Progress in Physical Geography, 25, 326-354. http://ppg.sagepub.com/cgi/content/abstract/25/3/326 https://doi.org/10.1191/030913301680193805

[3] Gibbs, H., Brown, S., Niles, J.O. and Foley, J.A. (2007) Monitoring and Estimating Tropical Forest Carbon Stocks: Making REDD a Reality. Environmental Research Letters, 2, Article ID: 045023. http://iopscience.iop.org/1748-9326/8/2/024024 https://doi.org/10.1088/1748-9326/2/4/045023

[4] Sedlacek, O., Reif, J., Horak, D., et al. (2007) The Birds of a Montane Forest Mosaic in Big Babanki Area, Bamenda Highlands, Cameroon. Malimbus, 29, 89-100.

[5] WWF (2007) Congo Basin Forests. World Wide Fund for Nature, 4 p.

[6] Pragasan, L.A. and Parthasarathy, N. (2010) Landscape-Level Tree Diversity Assessment in Tropical Forests of Southern Eastern Ghats, India. Flora, 205, 728-737. https://doi.org/10.1016/j.flora.2010.04.011

[7] Chomitz, K.M., Buys, P., Luca, G.D., et al. (2007) At Loggerheads? Agricultural Expansion, Poverty Reduction and Environment in Tropical Forests. World Bank Policy Research Report. The World Bank, Washington DC.

[8] Achard, F., Eva, H.D., Stibig, H.J., et al. (2002) Determination of Deforestation Rates of the World's Humid Tropical Forests. Science, 297, 999-100. https://doi.org/10.1126/science.1070656

[9] Geist, H.J. and Lambin, E.F. (2002) Proximate Causes and Underlying Driving Forces of Tropical Deforestation. BioScience, 52, 143-150. https://doi.org/10.1641/0006-3568(2002)052[0143:PCAUDF]2.0.CO;2

[10] Eyebe, A.J., Simeon, A.E., Angu, K.A. and Endamana, D. (2012) Integrating Biodiversity Conservation into National Development Policy: A Case Study of Cameroon. Poverty and Conservation Learning Group, 9, 18.

[11] Tchawa, P. (2012) Le Cameroun une Afrique en miniature? Les Cahiers d Outre-Mer, 259, 319-338. https://doi.org/10.4000/com.6640

[12] De Wasseige, C., de Marcken, P., Bayol, N., et al. (2012) The Forests of the Congo Basin-State of the Forest 2010. Publications Office of the European Union, Luxembourg, $276 \mathrm{p}$.

[13] Tyukavina, A., Hansen, M.C., Potapov, P., et al. (2018) Congo Basin Forest Loss Dominated by Increasing Smallholder Clearing. Science Advances, 4, eaat2993. https://doi.org/10.1126/sciadv.aat2993

[14] MINEF (1999) A Compendium of Official Instruments on Forest and Wildlife Management in Cameroun: Legal Regulations on Forestry and Wildlife, Specific Regulatory Instruments on Forestry and Wildlife Management, Common Instruments of Forestry and Wildlife Management. National Printing Press, Yaoundé.

[15] FAO (2007) State of the World's Forests. Food and Agricultural Organization of the 
United Nations, Rome.

[16] FAO (2005) Global Forest Resource Assessment 2000-Main Report. FAO Forestry Paper No. 140. Rome.

[17] Ingram, V. and Nsawir, A.T. (2007) Pygeum: Money Growing on Trees in the Cameroon Highlands? Nature \& Fauna, 22, 29-36.

[18] Ineich, I., LeBreton, M., Lhermitte-Vallarino, N. and Chirio, L. (2015) The Reptiles of the Summits of Mont Oku and the Bamenda Highlands, Cameroon. Amphibian \& Reptile Conservation, 9, 15-38.

[19] Conservation International (2004) Biodiversity Hotspots Revisited, Conservation Synthesis. Center for Applied Biodiversity Science at Conservation International, Washington DC.

[20] BirdLife International (2019) Endemic Bird Areas factsheet: Cameroon Mountains. Birdlife International, Washington DC.

[21] Ndenecho, E.N. (2005) Savannization of Tropical Montane Cloud Forests in the Bamenda Highlands, Cameroon. Journal of the Cameroon Academy of Sciences, 5, 3-10.

[22] Ambebe, T.F., Zee, F.G. and Shu, M.A. (2018) Modeling of Leaf Area of Three Afromontane Forest Tree Species through Linear Measurements. Journal of Research in Ecology, 6, 2334-2341. http://ecologyresearch.info/documents/EC0629.pdf

[23] Ndenecho, E.N. (2010) Implications of Fuel Wood Yield, Availability and Harvest in Tubah Mountain Forest, Cameroon. Global Journal of Human Social Science, 10, 49-55.

[24] Noumi, E. and Tiam, G.A.T. (2016) Floristic Inventory of Woody Species of the Oku Sacred Forest in the North-West Cameroon, Theoretical and Philosophical Approach. International Journal of Current Research in Biosciences and Plant Biology, 3, 2349-8080. https://doi.org/10.20546/ijcrbp.2016.301.009

[25] Tchouto, M.P.G. (2004) Plant Diversity in a Central African Rain Forest: Implication for Conservation in Cameroon. Ph.D. Thesis, Wageningen University, Wageningen, $208 \mathrm{p}$.

[26] Letouzey, R. (1985) Notice de la carte phytogéographique du Cameroun au 1: 500 000. 5 Vols. Institut de la carte Internationale de la Végétation, Toulouse.

[27] Letouzey, R. (1968) Etude phytogéographique du Cameroun. Paul Lechevallier, Paris.

[28] Hutchinson, J., Dalziel, J. and Keay, R. (1958) Flora of West Tropical Africa. Volume 1. Crown Agents for Overseas Governments \& Administrations, London, 828 p.

[29] Normand, D. (1965) Central African Republic (Woody Plants) 575,487.

[30] Vivien, J. and Faure, J.J. (1985) Arbres des forêts denses d'Afrique centrale. Ministère des relations extérieures, Coopération et Développement-ACCT, Paris, 551.

[31] Liping, C., Yujun, S. and Saeed, S. (2018) Monitoring and Predicting Land Use and Land Cover Changes Using Remote Sensing and GIS Techniques-A Case Study of a Hilly Area, Jiangle, China. PLoS ONE, 13, e0200493. https://doi.org/10.1371/journal.pone.0200493

[32] Kacholi, D.S. (2014) Analysis of Structure and Diversity of the Kilengwe Forest in the Morogoro Region, Tanzania. International Journal of Biodiversity, 2014, Article ID: 516840. https://doi.org/10.1155/2014/516840

[33] Shannon, C.E. and Wiener, W. (1963) The Mathematical Theory of Communication. 
University of Illinois Press, Urbana, 127 p.

[34] Sørensen, T. (1948) A Method of Establishing Groups of Equal Amplitude in Plant Sociology Based on Similarity of Species and Its Application to Analyses of the Vegetation on Danish Commons. Biologiske Skrifter, 5, 1-34.

[35] Vicente-Serrano, S.M., Camarero, J.J., Olano, J.M., et al. (2016) Diverse Relationships between Forest Growth and the Normalized Difference Vegetation Index at a Global Scale. Remote Sensing of Environment, 187, 14-29. https://doi.org/10.1016/j.rse.2016.10.001

[36] Berberoglu, S., Evrendilek, F. and Ozkan, C. (2007) Modeling Forest Productivity Using Envisat MERIS Data. Sensors, 7, 2115-2127. https://doi.org/10.3390/S7102115

[37] Xiaoling, C., Xiaobin, C. and Hui, L. (2006) Expert Classification Method Based on Patch-Based Neighborhood Searching Algorithm. Geo-Spatial Information Science, 10, 37-43. https://doi.org/10.1007/s11806-006-0145-y

[38] Van Rooyen, M., Van Rooyen, N., Orban, B., et al. (2017) Floristic Composition, Diversity and Structure of the Forest Communities in the Kouilou Département, Republic of Congo. Tropical Ecology, 57, 805-824.

[39] Noumi, E. (2014) Floristic Inventory of Woody Species in the Manengouba Mountain Forest, Cameroon. Journal of Biology and Life Science, 4, 2157-6076. https://doi.org/10.5296/jbls.v6i1.7028

[40] Ndam, N., Acworth, J., Kenfack, D. and Hall, J.B. (2001) Plant Diversity Assessment on Mount Cameroon: Surveys from 1990 to 2000. Systematics and Geography of Plants, 71, 1017-1022. https://doi.org/10.2307/3668735

[41] Fonge, B.A., Tchetcha, D.J. and Nkembi, L. (2013) Diversity, Distribution and Abundance of Plants in Lewoh-Lebang in the Lebialem Highlands of South Western Cameroon. International Journal of Biodiversity, 2013, Article ID: 642579. https://doi.org/10.1155/2013/642579

[42] Kenfack, D., Duncan, E.W.T., Chuyong, G.B. and Condit, R. (2007) Rarity and Abundance in a Diverse African Forest. Biodiversity and Conservation, 16, 2045-2074. https://doi.org/10.1007/s10531-006-9065-2

[43] Kouamé, D., Abdou, Y.C.Y., Kouassi, K.E., et al. (2008) Preliminary Floristic Inventory and Diversity in Azagny National Park (Côte d'Ivoire). European Journal of Scientific Research, 23, 537-547.

[44] Egbe, E.A., Chuyong, G.B., Fonge, B.A. and Namuene, K.S. (2012) Forest Disturbance and Natural Regeneration in African Rainforest at Korup National Park, Cameroon. International Journal of Biodiversity and Conservation, 4, 377-384.

https://doi.org/10.5897/IJBC12.031

[45] Coley, P.D. and Barone, J.A. (1996) Herbivory and Plant Defenses in Tropical Forests. Annual Review of Ecology and Systematics, 27, 305-335.

https://doi.org/10.1146/annurev.ecolsys.27.1.305

[46] Njoh, N.R., Egbe, E.A. and Bechem, E. (2013) Species Composition, Diversity and Distribution in a Disturbed Takamanda Rainforest, South West, Cameroon. African Journal Plant Science, 7, 577-585. https://doi.org/10.5897/AJPS2013.1107

[47] Parthasarathy, N. (1999) Tree Diversity and Distribution in Undisturbed and Human-Impacted Sites of Tropical Wet Evergreen Forest in Southern Western Ghats, India. Biodiversity and Conservation, 8, 1365-1381. https://doi.org/10.1023/A:1008949407385

[48] Chauhan, P.S., Negi, J.D.S., Singh, L. and Manhas, R.K. (2008) Regeneration of Sal 
Forests of Doon Valley. Annals of Forestry, 16, 178-182.

[49] IUCN (2006) International Union for Conservation of Nature and Natural Resources Red List of Threatened Species. IUCN Global Species Programme Red List Unit, Cambridge.

[50] Misra, V.N. (1989) Stone Age India: An Ecological Perspective. Man and Environment, 14, 17-64.

[51] Barlow, J., Gardner, T.A., Araujo, I.S., et al. (2007) Quantifying the Biodiversity Value of Tropical Primary, Secondary, and Plantation Forests. Proceedings of the National Academy of Sciences, 104, 18555-18560.

https://doi.org/10.1073/pnas.0703333104

[52] Sala, O.E., Chapin, I.F.S., Armesto, J.J., et al. (2000) Global Biodiversity Scenarios for the Year 2100. Science, 287, 1770-1774.

https://doi.org/10.1126/science.287.5459.1770 